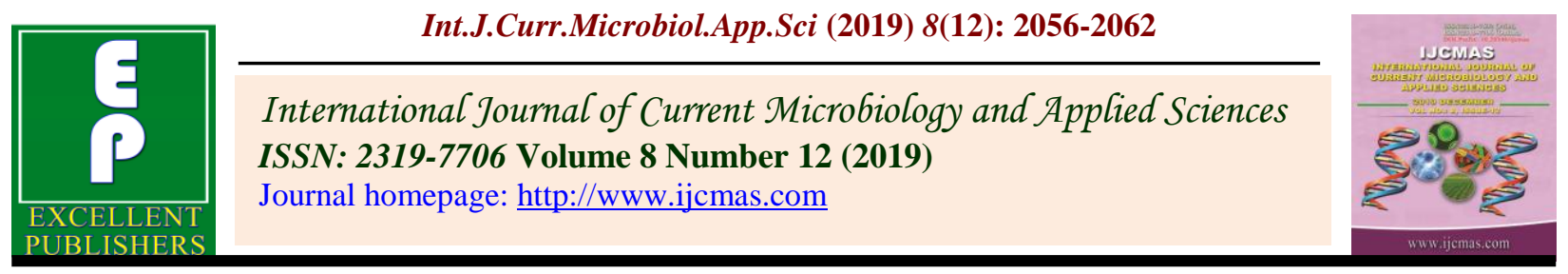

Original Research Article

https://doi.org/10.20546/ijcmas.2019.812.243

\title{
Effect of Plastic Mulch on Growth and Yield of Chilli (Capsicum annuum L.)
}

\author{
Pankaj Maida*, B. P. Bisen and Garima Diwan \\ Department of Horticulture, College of Agriculture, JNKVV, Jabalpur (M.P.) 482004, India \\ *Corresponding author
}

\section{A B S T R A C T}

Keywords

Chilli, Mulch:

black, Silver/black

plastic, Soil

temperature, Soil

moisture

Article Info

Accepted:

15 November 2019

Available Online:

10 December 2019
The present investigation was carried out during Rabi season of 2017-2018 at the Horticulture complex, Department of Horticulture, College of Agriculture, Jawaharlal Nehru Krishi Vishwa Vidyalaya, Jabalpur (M.P.). The treatments consisting of twocoloured polyethylene mulch (black, silver/black) and with bare soil (without mulch) as controls. Results showed that soil temperature under the various coloured mulches was 2 to $4^{\circ} \mathrm{C}$ warmer compared to bare soil. The highest soil temperature was recorded under black mulch (20.63). The plants grown on silver/black mulch produced Maximum plant heights $(48.83 \mathrm{~cm}$.), primary branches/plant $(13.74)$, secondary branches/plant (21.13), early flowering (17.19), fruit length $(8.74 \mathrm{~cm})$, Fruit diameter $(0.88 \mathrm{~cm})$, average weight of fruit $(4.49 \mathrm{~g})$, number of fruits/plant $(155.25)$, fruit yield/plant $(744.14 \mathrm{~g})$, Fruit yield per plot $(11.82 \mathrm{~kg})$, Ascorbic acid $(269.07 \mathrm{mg} / 100$ $\mathrm{g}$ ), water use efficiency $\left(4.96 \mathrm{~kg} \mathrm{ha}^{-1}-\mathrm{mm}\right)$, moisture depletion pattern $\%$ and soil temperature under different stages. Under without mulch condition, recorded maximum days taken to $50 \%$ flowering (24.58), maximum total soluble solids $\left(2.38^{\circ}\right.$ Brix), weeds fresh weight $(41.49 \mathrm{~g})$ and weeds dry weight $(11.48 \mathrm{~g})$.In an attempt to reducing chemical input for weed control and increase to yield of chilli black and silver/black plastic mulch may be a good alternative for conventional without mulch.

\section{Introduction}

Chilli (Capsicum annum L.) is considered as one of the commercial spice crops. It is the most widely used universal spice, named as wonderspice. Different varieties are cultivated for various uses like vegetable, pickles, spice and condiments. In daily life, chillies are the most important ingredient in many different countries around the world as it adds pungency, taste, flavour and colour to the dishes. India is the largest producer, consumer and exporter of chilli and contributes to $25 \%$ of total world's production. In India, chilli is grown in almost all the states across the length and breadth of the country. Andhra Pradesh the largest producer of chilli in India, contributes about $30 \%$ to the total area under chilli, followed by Karnataka (20\%), Maharashtra (15\%), Orissa (9\%), Tamil Nadu 
(8\%) and other states contributing $18 \%$. In India, it occupies an area of $792 \mathrm{MH}$ with a production of 1376 MT with an average productivity of1643 kg/ha. (NHB 2015-16). Madhya Pradesh is the Chilli producing area with 88000 ha, production 70000 tonnes and productivity $795 \mathrm{~kg} / \mathrm{ha}$ of Chilli (Anonymous, 2015-16). Chilli is increasing in its popularity for its pungent fruits and is highest in vitamin A \&C, Iron and calcium. Chillies are used in making chilli vinegar, hot oil, tomato sauces, rice dishes, soups, hot condiments such as samber, beans, corn and curry powders. Chillies do well with several other spices including basil, ginger, oregano, cilantro, cinnamon, black pepper, fennel and cumin. Mulching is the practice of covering the soil around plants to make conditions more favourable for growth, development and efficient crop production (Nagalakshmi et al., 2002). Mulches are used for the moderation of soil temperature, through the effects were highly variable. Colour of mulch affected soil temperatures. White (or) reflective plastic decreased temperatures (Unger 1984). Hot days, soil temperature under straw mulch was reduced as much as $17^{\circ} \mathrm{C}\left(30^{\circ} \mathrm{F}\right)$ lower than un-mulched plots (Yamaguchi, 1983). Mulches of plant material like straw, dry grass and leaves etc. reduced the soil temperatures (Dhesi et al., 1964). Black polyethylene induces soil temperature, more moisture conservation higher soil microbial activity resulting in more mineralization and availability of nutrients to the plant (Patil and Bansod, 1972).

\section{Materials and Methods}

A field experiment was carried out during Rabi season of 2017-2018 at the Horticulture complex, Department of Horticulture, College of Agriculture, Jawaharlal Nehru Krishi Vishwa Vidyalaya, Jabalpur, Madhya Pradesh. The experiment was conducted for comparative study and influence of effect of mulch on performance of chilli cv. ArkaLohit, in Factorial Randomized Block Design experiment with three replications using three type of mulching as treatments i.e., no mulch (M0), Black plastic mulch (M1) and silver plastic mulch (M2). The Black plastic mulch and silver plastic mulch (low density polyethylene) of 25 micron thickness was fixed tightly during the non-windy period without any crease to cover the soil surface both ends of the plastic were buried into the soil up to the depth of $10 \mathrm{~cm}$. Seedlings were immersed in holes at $60 \times 50 \mathrm{~cm}$ spacing of polyethylene of sheet. Plots were $4 \times 1.2 \mathrm{~m}$ on $15 \mathrm{~cm}$ high raised beds. Drip irrigation tubing was placed under mulches during the same process. The site was fertilized according to soil test recommendations. In control plots, no herbicides were applied and any weed escapes were controlled by bi-weekly hand weeding. Seeds of chillies were sown at nursery (low tunnel covered with clear plastic) on 5 sep. 2017. On 28 Oct., Fifty -day old seedlings were transplanted by making holes of $5 \mathrm{~cm}$ diameter. Soil temperature was measured at 10 $\mathrm{cm}$ depth for all treatments using soil thermometer.

Observations were recorded on the basis of five random competitive plants selected from each treatment separately for morphological, phenological and yield characters were evaluated. Weeds were collects from plots and took their fresh and oven dried weight at harvest time.

\section{Results and Discussion}

\section{Effect of mulch on growth characters}

The data on various growth parameters i.e. plant height, number of primary and secondary branches per plant, flowering as influenced by different mulching and irrigation levels are presented in the Table 1 and 2 . 


\section{Effect of mulch}

Among mulching treatments different growth parameters significantly influenced. The data among mulching treatments (Table 1 and 2) showed that plant height in silver plastic mulch recorded maximum height (32.0, 36.75, $40.20,48.83 \mathrm{~cm})$ followed by black plastic mulch $(29.19,35.20,39.25,46.28 \mathrm{~cm})$ and minimum plant height $(25.80,31.57,35.10$, $41.39 \mathrm{~cm}$ ) was observed in no mulch condition at 30, 45, 60 and 90 DAT respectively. In the case of primary branches per plant, recorded maximum number of primary branches per plant in silver plastic mulch $(2.58,6.56,9.48$, 13.74)followed by black plastic mulch (2.23, $6.10,8.31,12.12)$ and minimum primary branches in no mulch condition $(1.56,3.90$, $6.63,10.81)$ at $30,45,60$ and 90 DAT respectively and in the secondary branches data indicated that in silver plastic mulch recorded maximum number of secondary branches $(9.14,17.86,21.13)$ and minimum number of secondary branches $(5.60,12.40$, $16.83)$ at 45,60 and 90 DAT respectively.

Days to flowering initiation and days taken to $50 \%$ flowering were significantly influenced by different mulching treatment. Among mulching treatments, no mulch recorded maximum days taken to flowering initiation (17.19) and days taken to 50\% flowering (24.58) and minimum days taken to flowering initiation (13.21), days taken to 50\% flowering (20.68)has been observed at silver plastic mulch. Early flower initiation may be due to the surface colour of plastic mulch can change the quantity of light and spectral balance reaching plants, with resulting effects on early initiation of flowers. In the other hand, plastic mulches often enhanced soil temperatures under the mulch covering and provided plants early season growth boost and higher growth may be due to reflected sun light and less evapo-transpiration and maintain soil moisture compare to black mulch condition. The microclimate condition improved by the mulches might have provided a suitable condition for producing higher plant height and number of primary and secondary branches in the plants. Similar findings were reported by Ashrafuzzaman et al., (2011) in chilli, Gordon et al., (2010) in okra and Christopher et al., (1996) in tomato.

\section{Effect of mulch on fruit characters}

The beneficial effects of mulching treatments were subsequently reflected in yield attributes like fruit length, average fruit weight, circumference of fruit, number of fruits per plant yield per plant and fruit yield per plot. A perusal of data given in Table 2, indicates that the fruit length, Fruit Diameters $(\mathrm{cm})$, Average weight of fruit $(\mathrm{g})$ were significantly influenced by different types of mulch.

\section{Effect of mulch}

Among mulching treatments, silver plastic mulch recorded maximum fruit length (8.74), maximum Fruit diameter (0.88), maximum average weight of fruit (4.49) followed by black plastic mulch $(8.21,0.85, \quad 4.33)$ respectively and minimum fruit length (7.53), minimum Fruit diameter (0.80), minimum average weight of fruit (3.59) were observed in no mulch condition. Higher fruit length in mulch treatments might be due to its effects on soil temperature, soil moisture and weed suppression. Reflected sun light and less evapo-transpiration and maintain soil moisture compare to no mulch. Similar findings were reported by Singh and Kamal (2012) in tomato.

\section{Effect of mulch on yield and quality characters}

Data pertaining in Table 3 indicate the number of fruits per plant, fruit yield per plant, fruit yield per plot, total soluble solids ( ${ }^{\circ}$ Brix), 
ascorbic acid (mg/ $100 \mathrm{~g}$ ) have been significantly influenced by different types of mulch.

\section{Effect of mulch}

Among mulching treatments, silver plastic mulch recorded maximum number of fruit plant, fruit yield per plant, fruit yield per plot $(155.25,744.14 \mathrm{~g}, 11.82 \mathrm{~kg})$ respectively, followed by black plastic mulch (145.75, $665.50 \mathrm{~g}, 10.61 \mathrm{~kg}$ ) respectively and minimum number of fruit plant, fruit yield per plant, fruit yield per plot $(138.33,579.22 \mathrm{~g}, 8.99 \mathrm{~kg}$ ) respectively, were observed in no mulch condition.

The increase in the fruit yield of mulched plot was probably associated with the conservation of moisture and improved microclimate both beneath and above the soil surface. The suitable condition enhanced the plant growth and development and produced increased fruit bearing nodes compared to the control. Similar finding was reported by Ashrafuzzaman et al., (2011) in chilli.

Among mulching treatments, silver plastic mulch recorded maximum Ascorbic acid (269.07 $\mathrm{mg}$ ) followed by black plastic mulch (258.46 mg) and minimum Ascorbic acid observed was $(227.22 \mathrm{mg})$ in no mulch condition. Higher total soluble solids were recorded in no mulch condition $\left(2.38^{\circ} \mathrm{Brix}\right)$ followed by black plastic mulch $\left(1.84^{\circ} \mathrm{Brix}\right)$ and minimum total soluble solids $\left(1.60^{\circ} \mathrm{Brix}\right)$ was observed at silver plastic mulch. This may be due to more evaporations losses which resulted in high percentage in TSS.

Decrease of TSS percentage with mulches may be due to high moisture conservation through frequent irrigation levels. Minimum total soluble solids were obtained with no mulch can be attributed to low soil water tension maintained under no mulch which lead to higher water uptake and hence dilution of the concentration of the total soluble solids (Kere et al., 2003).

\section{Effect of mulch on weeds}

A perusal of data given in Table 4 indicates that the weeds fresh weight, Weeds biomass (g), Water use efficiency $\left(\mathrm{kg} \mathrm{ha}^{-1-\mathrm{mm}}\right)$ were significantly influenced by different types mulching.

\section{Effect of mulch}

Among mulching treatments, no mulch recorded maximum weeds fresh weight (41.49 g), maximum weeds dry weight (11.48) followed by silver plastic mulch $(8.40 \mathrm{~g}, 2.41$ g) respectively and minimum weeds fresh weight and minimum weeds dry weight (7.26 g, $2.19 \mathrm{~g})$ respectively, observed at black plastic mulch. It is due to transparent plastic mulch produced maximum weed population and dry matter which might be due to direct entrance of solar radiation through them and as well as due to higher soil temperature There was complete elimination of weeds under black polyethylene mulch. Similar findings were also reported by Ramakrishna et al., (2006) in groundnut in tomato. Silver plastic mulch has recorded significantly maximum mean consumptive use of water followed by black plastic mulch. It may be due to reflected sun light and less evapotranspiration and maintain soil moisture compare to no mulch in plant. Similar findings were recorded by Mukherjee et al., (2010) in tomato.

\section{Effect of mulch on soil moisture depletion pattern (\%) and variation in soil temperature at different stage}

A perusal of data given in Table 5 indicates that the soil moisture depletion pattern (\%) and variation in soil temperature have been significantly influenced at different stage by different mulching treatment. 
Table.1 Effect of mulch on growth characters

\begin{tabular}{|c|c|c|c|c|c|c|c|c|}
\hline Treatment & \multicolumn{4}{|c|}{ Plant Height $(\mathrm{cm})$} & \multicolumn{4}{|c|}{ Primary branches } \\
\hline $\begin{array}{l}\text { Mulching } \\
\text { (M) }\end{array}$ & 30 DAT & 45 DAT & 60 DAT & 90 DAT & 30 DAT & 45 DAT & 60 DAT & 90 DAT \\
\hline $\mathbf{M}_{\mathbf{0}}$ & 25.80 & 31.57 & 35.10 & 41.39 & 1.56 & 3.90 & 6.63 & 10.81 \\
\hline $\mathbf{M}_{1}$ & 29.19 & 35.20 & 39.25 & 46.28 & 2.23 & 6.10 & 8.31 & 12.12 \\
\hline $\mathbf{M}_{2}$ & 32.00 & 36.75 & 40.20 & 48.83 & 2.58 & 6.56 & 9.48 & 13.74 \\
\hline S.Em. \pm & 0.060 & 0.061 & 0.039 & 0.080 & 0.057 & 0.075 & 0.050 & 0.058 \\
\hline C.D.@ 5\% & 0.178 & 0.180 & 0.116 & 0.237 & 0.168 & 0.221 & 0.148 & 0.171 \\
\hline
\end{tabular}

Note: DAT- Days After Transplanting

Factor A- Mulching - $\quad \mathrm{M}_{\mathrm{O}}$ : No Mulch $\quad \mathrm{M}_{1}$ : Black Mulch $\mathrm{M}_{2}$ : Silver Mulch

Table.2 Effect of mulch on growth characters

\begin{tabular}{|c|c|c|c|c|c|}
\hline Treatment & \multicolumn{3}{|c|}{ Secondary branches } & Flowering initiation & Days taken to $50 \%$ \\
\hline Mulching (M) & 45 DAT & 60 DAT & 90 DAT & & \\
\hline $\mathbf{M}_{0}$ & 5.60 & 12.40 & 16.83 & 17.19 & 24.58 \\
\hline$M_{1}$ & 7.74 & 15.61 & 19.22 & 14.13 & 21.70 \\
\hline $\mathbf{M}_{2}$ & 9.14 & 17.86 & 21.13 & 13.22 & 20.68 \\
\hline S.Em. \pm & 0.062 & 0.033 & 0.042 & 0.045 & 0.061 \\
\hline C.D.@5\% & 0.183 & 0.097 & 0.123 & 0.133 & 0.180 \\
\hline
\end{tabular}

Table.3 Effect of mulch on Fruit characters

\begin{tabular}{|c|c|c|c|}
\hline Treatment & \multirow[t]{2}{*}{ Fruit length (cm) } & \multirow[t]{2}{*}{ Fruit Diameters (cm) } & \multirow[t]{2}{*}{ Average weight of fruit (g) } \\
\hline Mulching (M) & & & \\
\hline$M_{0}$ & 7.53 & 0.80 & 3.59 \\
\hline $\mathbf{M}_{1}$ & 8.21 & 0.85 & 4.33 \\
\hline $\mathbf{M}_{2}$ & 8.74 & 0.88 & 4.49 \\
\hline S.Em. \pm & 0.051 & 0.005 & 0.042 \\
\hline C.D.@5\% & 0.149 & 0.016 & 0.125 \\
\hline
\end{tabular}

Table.4 Effect of mulch on yield and quality characters

\begin{tabular}{|c|c|c|c|c|c|}
\hline $\begin{array}{c}\text { Treatment } \\
\text { Mulching } \\
\text { (M) }\end{array}$ & $\begin{array}{l}\text { Number of } \\
\text { fruits plant }^{-1}\end{array}$ & $\begin{array}{c}\text { Fruit } \\
\text { yield } \\
\text { Plant }^{-1}(\mathrm{~g})\end{array}$ & $\begin{array}{c}\text { Fruit } \\
\text { yield } \\
\text { Plot }^{-1}(\mathrm{~kg})\end{array}$ & $\begin{array}{l}\text { Total soluble } \\
\text { solids ( }{ }^{\circ} \text { Brix) }\end{array}$ & $\begin{array}{l}\text { Ascorbic acid } \\
\text { content } \\
\text { (mg/100 mg) }\end{array}$ \\
\hline $\mathbf{M}_{\mathbf{0}}$ & 138.33 & 579.22 & 8.99 & 2.38 & 227.22 \\
\hline $\mathbf{M}_{1}$ & 145.75 & 665.50 & 10.61 & 1.84 & 258.46 \\
\hline $\mathbf{M}_{2}$ & 155.25 & 744.14 & 11.82 & 1.60 & 269.07 \\
\hline S.Em. \pm & 0.451 & 4.182 & 0.047 & 0.068 & 2.079 \\
\hline C.D.@ 5\% & 1.330 & 12.350 & 0.140 & 0.201 & 6.136 \\
\hline
\end{tabular}


Table.5 Effect of mulch on weeds

\begin{tabular}{|c|c|c|c|}
\hline $\begin{array}{c}\text { Treatment } \\
\text { Mulching (M) }\end{array}$ & Weeds fresh weight (g) & Weeds biomass (g) & $\begin{array}{l}\text { Water use efficiency } \\
\left(\mathrm{kg} \mathrm{ha}^{-1} \mathbf{~ m m}\right)(\mathbf{k g})\end{array}$ \\
\hline $\mathbf{M}_{0}$ & 41.49 & 11.48 & 3.11 \\
\hline $\mathbf{M}_{1}$ & 7.26 & 2.19 & 4.24 \\
\hline $\mathbf{M}_{2}$ & 8.40 & 2.41 & 4.97 \\
\hline S.Em. \pm & 0.074 & 0.056 & 0.030 \\
\hline C.D.@5\% & 0.217 & 0.165 & 0.089 \\
\hline
\end{tabular}

Table.6 Effect of mulch on Soil moisture depletion pattern(\%) and Variation in soil temperature at different stage

\begin{tabular}{|c|c|c|c|c|c|}
\hline Treatment & \multicolumn{2}{|c|}{ Soil moisture depletion pattern (\%) } & \multicolumn{3}{|c|}{ Soil Temperature at different stage $\left({ }^{\circ} \mathrm{C}\right)$} \\
\hline $\begin{array}{l}\text { Mulching } \\
\text { (M) }\end{array}$ & $\begin{array}{c}\text { Fruit maturity } \\
\text { stage (0- } 15 \mathrm{~cm} \\
\text { depth) }\end{array}$ & $\begin{array}{c}\text { Fruit maturity } \\
\text { stage } \\
\text { (15- } 30 \mathrm{~cm} \text { depth) }\end{array}$ & $\begin{array}{l}\text { Vegetative } \\
\text { phase } \\
\text { at } 30 \mathrm{DAT}\end{array}$ & $\begin{array}{c}\text { Flowering } \\
\text { initiation } \\
\text { stage }\end{array}$ & $\begin{array}{c}\text { Days to } \\
\text { first } \\
\text { harvest }\end{array}$ \\
\hline $\mathbf{M}_{0}$ & 24.10 & 19.94 & 17.43 & 18.28 & 18.27 \\
\hline $\mathbf{M}_{1}$ & 31.80 & 23.77 & 20.63 & 20.67 & 20.63 \\
\hline $\mathbf{M}_{2}$ & 32.63 & 24.67 & 20.51 & 20.50 & 20.53 \\
\hline S.Em. \pm & 0.139 & 0.050 & 0.062 & 0.044 & 0.046 \\
\hline C.D.@5\% & 0.410 & 0.147 & 0.182 & 0.129 & 0.135 \\
\hline
\end{tabular}

\section{Effect of mulch}

Among mulching treatments, silver plastic mulch recorded maximum soil moisture depletion at fruit maturity stage in the depth of $0-15 \mathrm{~cm}$ and $15-30 \mathrm{~cm}(32.63,24.67)$, followed by black plastic mulch $(31.80,23.77)$ and minimum soil moisture depletion (24.10, 19.94) respectively, observed in no mulch condition (Table 6).

Among mulching treatments, black plastic mulch recorded maximum soil temperature at vegetative phase at 30 DAT, flowering initiation stage, days to first harvest (temp.) $(20.63,20.67,20.63)$ respectively, followed by silver plastic mulch $(20.51,20.50,20.53)$ respectively and minimum soil temperature $(17.43, \quad 18.28,18.27)$ respectively, were observed in no mulch condition. It is due to using black plastic mulch increase 3.3 to 6.6 ${ }^{\circ} \mathrm{C}$ observed radiation to pass through and store in soil.

Similar results were reported by Decoteau et al., (1990), Ham and Kluitenberg (1994), Tarara (2000) and Dodds et al., (2003).

On the basis of present investigation, it is concluded that the chilli cv. ArkaLohit responded well in terms of morphological, phonological, yield attributing character and quality parameters.

Maximum yield the chilli crop can be silver mulch. Higher water productivity and yield can be obtained by application of silver/ black polythene mulch. To get maximum net profits, the chilli crop can be safely application of silver polythene mulch. 


\section{References}

Anonnymous. 2015. National Horticulture Baord, Gurgaon (Hariyana), India.

Ashrafuzzaman M, Abdul Halim M, Mohd Razi Ismail, S.M. Shahidullah and Alamgir Hossain, M. 2011. Effect of Plastic Mulch on growth and yield of chilli. Braz. Arch. Biol. Technol. 54(2): 321-330.

Christopher Lourduraj A, Sreenarayanan VV, Rajendran R Rani V, Padmini K and Pandiarajan T. 1996. Effect of Plastic mulching on tomato yield and economics. South Indian Horticulture, 44 (5 \& 6) $139-142$.

Decoteau DR, Kasperbauer MJ and Hunt PG. 1990. Bell pepper plant development over mulches of diverse colors. Hort. Sci. 25(4):460-462.

Dhesi N S, Nandpuri K S and Amar Singh 1964 Effect of mulching and irrigation on the soil temperature for potato culture. Indian Journal of Agronomy 9:277-280.

Dodds GT, Madramootoo C. A Janik DE, Fava and Stewart A. 2003. Factors affecting soil temperatures under plastic mulches. Trop. Agric. (Trinidad) 80: 6- 13.

Gordon GG, Foshee GW, Reed ST, Brown JE and Vinson EL. 2010. "The effects of colored plastic mulches and row covers on the growth and yield of okra," Hort Technology, 20(1): 224233.

Ham JM and Kluitenberg GJ. 1994. Modeling the effect of mulch optical properties and mulch-soil contact resistance on soil heating under plastic mulch culture. Agr. For. Meteorology 71: 403-424.

Kere GM, Nyanjage MO, Liu G and Nyalala SPO. 2003. Influence of drip irrigation schedule and mulching material on yield and quality of greenhouse tomato (Lycopersicon esculentum). Asian Journal of Plant Science. 2(14): 10521058

Mukherjee A, Kundu M and Sarkar S. 2010. Role of irrigation and mulch on yield, evapotranspiration rate and water use pattern of tomato (Lycopersicon esculentum L). Agricultural Water Management. 98: 182-189.

Nagalakshmi S, Palanisamy D, Eswaran S and Sreenarayanan VV. 2002. Influence of plastic mulching on chilli yield and economics. South Indian Horticulture 50 (1-3): 262-265.

Patil A V and Bansod A D.1972. Effect of mulching treatment on soil properties, growth and yield of tomato (var. Siouk). Indian Journal Horticulture, 29(2): 197-205.

Ramakrishna A M, Hoang T, Suhas PW and Tranh DL. 2006. Effect of mulch on soil temperature, moisture, weed infestation and yield of groundnut in northern Vietnam. Field Crops Res. 95: 1.

Singh AK, and Shashi K. Effect of black plastic mulch on soil temperature and tomatoyield in mid hills of Garhwal Himalayas. Journal of Horticulture and Forestry. 2012, 4(4): 78-80

Tarara JM. 2000. Microclimate modifications with plastic mulch. HortScience, 35(2):1 69-180.

\section{How to cite this article:}

Pankaj Maida, B. P. Bisen and Garima Diwan. 2019. Effect of Plastic Mulch on Growth and Yield of Chilli (Capsicum annuum L.). Int.J.Curr.Microbiol.App.Sci. 8(12): 2056-2062. doi: https://doi.org/10.20546/ijcmas.2019.812.243 